OPEN ACCESS

Edited by: Victor Flors,

Jaume I University, Spain

Reviewed by:

Eugenio Llorens,

Tel Aviv University, Israel

Maria Rosa Marano,

IBR-CONICET and Universidad

Nacional de Rosario, Argentina

*Correspondence:

Tae-Hwan Kim

grass@@chonnam.ac.kr; grass/@jnu.ac.kr

these authors have contributed equally to this work.

Specialty section: This article was submitted to Plant Microbe Interactions, a section of the journal

Frontiers in Plant Science

Received: 13 September 2017 Accepted: 29 November 2017 Published: 12 December 2017

Citation: Islam MT, Lee B-R, Park S-H, La VH, Bae D-W and Kim T-H (2017) Cultivar Variation in Hormonal Balance Is a Significant Determinant of Disease Susceptibility to Xanthomonas campestris pv. campestris in Brassica napus. Front. Plant Sci. 8:2121. doi: 10.3389/fp/s.2017.02121

\section{Cultivar Variation in Hormonal Balance Is a Significant Determinant of Disease Susceptibility to Xanthomonas campestris pv. campestris in Brassica napus}

\author{
Md. Tabibul Islam 1t, Bok-Rye Lee 1,2t, Sang-Hyun Park', Van Hien La', Dong-Won Bae ${ }^{3}$ \\ and Tae-Hwan Kim ${ }^{1 *}$
}

${ }^{1}$ Department of Animal Science, Institute of Agricultural Science and Technology, College of Agriculture and Life Science, Chonnam National University, Gwangju, South Korea, ${ }^{2}$ Biotechnology Research Institute, Chonnam National University, Gwangju, South Korea, ${ }^{3}$ Central Instrument Facility, Gyeongsang National University, Jinju, South Korea

This study aimed to directly elucidate cultivar variation in disease susceptibility and disease responses in relation to hormonal status in the interaction of Brassica napus cultivars and Xanthomonas campestris pv. campestris (Xcc), the causal agent of black rot disease. Fully expanded leaves of six B. napus cultivars (cvs. Capitol, Youngsan, Saturnin, Colosse, Tamra, and Mosa) were inoculated with Xcc. At 14 days postinoculation with $X_{c c}$, cultivar variation in susceptibility or resistance was interpreted with defense responses as estimated by redox status, defensive metabolites, and expression of phenylpropanoid synthesis-related genes in relation to endogenous hormonal status. Disease susceptibility of six cultivars was distinguished by necrotic lesions in the Xcc-inoculated leaves and characterized concurrently based on the higher increase in reactive oxygen species and lipid peroxidation. Among these cultivars, as the susceptibility was higher, the ratios of abscisic acid (ABA)/jasmonic acid (JA) and salicylic acid (SA)/JA tended to increase with enhanced expression of SA signaling regulatory gene NPR1 and transcriptional factor TGA1 and antagonistic suppression of JAregulated gene PDF 1.2. In the resistant cultivar (cv. Capitol), accumulation of defensive metabolites with enhanced expression of genes involved in flavonoids (chalcone synthase), proanthocyanidins (anthocyanidin reductase), and hydroxycinnamic acids (ferulate-5-hydroxylase) biosynthesis and higher redox status were observed, whereas the opposite results were obtained for susceptible cultivars (cvs. Mosa and Tamra). These results clearly indicate that cultivar variation in susceptibility to infection by Xcc was determined by enhanced alteration of the SAJJA ratio, as a negative regulator of redox status and phenylpropanoid synthesis in the Brasica napus-Xcc pathosystem.

Keywords: Brassica napus, disease susceptibility, hormonal balance, phenylpropanoid, redox, Xanthomonas campestris pv. campestris 


\section{INTRODUCTION}

Oilseed rape (Brassica napus L.), grown for the production of vegetable oil, animal feeds, and alternative fuel, is one of the major agro-economic crops. Xanthomonas campestris pv. campestris (Xcc), the causal agent of black rot, has become a major threat to Brassica species (Velasco et al., 2013). Disease symptoms caused by Xcc infection include $\mathrm{V}$-shaped necrotic lesions on leaves and darkening of vascular tissues with extensive necrosis and chlorosis (Aires et al., 2011). Pathogen invasion induces different plant-pathogen defense reactions, including susceptibility, resistance, or nonhost reactions (O’Donnell et al., 2003; Aires et al., 2011). One of the earliest physiological responses to pathogen infection is rapid reactive oxygen species (ROS) production (Venisse et al., 2001). ROS can reduce pathogen viability via direct antibacterial activity, and is also implicated in the oxidative damage of challenged plant cells through lipid peroxidation (Lee et al., 2007, 2013). ROS-scavenging systems are highly activated in resistance mechanisms, to scavenge the ROS and reduce oxidative stress. Glutathione (GSH) is one of the major nonenzymatic antioxidants present in a plant cell, which maintains the intracellular redox homeostasis by reducing cellular disulfide bonds (Finiti et al., 2014).

Over the recent decades, the roles of several phytochemicals, including secondary metabolites, in plant defense systems have been evaluated. Glucosinolates and its subsequent hydrolysis products play a role in the constitutive resistance of Brassicaceae to Xcc (Aires et al., 2011; Velasco et al., 2013). Plant phenolics are also involved in resistance against different plant diseases. In an integrated metabolo-proteomic study (Gunnaiah et al., 2012), metabolites of the phenylpropanoid pathway, such as hydroxycinnamic acid amides, phenolic glucosides, and flavonoids, were shown to be involved in resistance against Fusarium graminearum. Susceptibility of cabbage to Xcc infection also correlated with the decline in phenylalanine ammonia-lyase (PAL) activity and phenolic metabolite accumulation (Barman et al., 2015).

Plant hormones are major endogenous low molecular weight signal molecules involved in regulating mechanisms of resistance to pathogens. This regulation is achieved through the interplay of different signaling pathways, enabling each single hormone to assist or antagonize the others (Anderson et al., 2004; Sánchez-Vallet et al., 2012; Martínez-Medina et al., 2017). SA regulates the basal resistance and disease development in susceptible hosts (O’Donnell et al., 2003). In tomato-Xanthomonas campestris pv. vesicatoria (tomato$\mathrm{Xcv}$ ) interaction, ethylene (ET) synthesis is clearly dependent upon prior SA synthesis, and the removal of either hormone alters the course of symptom development, relative to the wild-type (O'Donnell et al., 2001). Several types of defense responses have been reported in Arabidopsis-Xanthomonas interactions. These defense responses include recognition of the pathogen, activation of signal transduction, and suppression of pathogen growth (Buell, 2002). A compatible interaction between SA-deficient mutant $(\mathrm{NahG})$ of Arabidopsis and Xcc showed substantially more rapid bacterial growth and more disease progression than the wild-type (O'Donnell et al., 2003). $\mathrm{ABA}$ is usually involved in disease resistance mechanisms of various plant species (Mohr and Cahill, 2003), and mutually antagonistic interactions have been reported between ABA and ET (Anderson et al., 2004). Recently, JA- and SA-regulated defense pathways in Trichoderma-induced resistance to the root-knot nematode have been characterized (Martínez-Medina et al., 2017). In recent decades, a network of communication, referred to as "hormonal crosstalk," among various hormone signaling pathways involved in pathogen resistance has been widely characterized by molecular studies based on experiments with mutant and transgenic lines (O'Donnell et al., 2001; Anderson et al., 2004; Sánchez-Vallet et al., 2012). However, the physiological significance of hormonal balance in disease resistance mechanisms has not been fully elucidated in hostpathogen interactions, especially in economic crops (MartínezMedina et al., 2017).

The present study focused on evaluation of varietal differences in susceptibility or resistance responses and the endogenous hormonal status upon infection by the pathogen Xcc. We used six cultivars of $B$. napus, which are most widely grown. We tested the hypothesis that shifting of the endogenous hormonal balance caused by Xcc inoculation modulates the susceptible-to-resistant responses of the host plant, leading to genotypic variation in disease susceptibility.

\section{MATERIALS AND METHODS}

\section{Plant Culture and Pathogen Inoculation}

Surface-sterilized seeds of six oilseed rape (B. napus) cultivars (Capitol, Youngsan, Saturnin, Colosse, Tamra, and Mosa) were grown in pots $(0.6 \mathrm{l})$. When the seedlings had grown up to the four-leaf stage, they were divided into two groups, i.e., the control and the one with pathogen inoculation. The pathogenic bacterial (X. campestris pv. campestris, Xcc) strain (KACC No10377) was obtained from the Korean Agricultural Culture Collection. Bacterium inoculum was cultured in Yeast Dextrose Calcium Carbonate (YDC) agar plate for $48 \mathrm{~h}$ at $30^{\circ} \mathrm{C}$, and then the bacterial cells were scraped from plates and adjusted to a concentration of $10^{8} \mathrm{CFU} / \mathrm{ml}(0.2 \mathrm{OD}$ A600 nm) with $0.85 \% \mathrm{NaCl}$ solution. The inoculation process was followed by clipping of the leaf edges near the veins using mouthtooth forceps. For every inoculation, the forceps was dipped into the bacterial suspension; the four youngest fully expanded leaves were inoculated. Fourteen days after inoculation, the leaves of Xcc non-inoculated (control) or Xcc-inoculated plants were, respectively, collected for the evaluation of different biochemical defense markers; they were immediately frozen in liquid nitrogen $(\mathrm{N})$ and stored in a deep freezer $\left(-80^{\circ} \mathrm{C}\right)$ for further analysis.

\section{Bacterial Populations}

Two leaf discs from distinct infiltrated leaves of different inoculated plants were sampled at 14 days after inoculation and were homogenized in $200 \mu \mathrm{l}$ sterile water. Serial dilutions of the homogenates were performed and $10 \mu \mathrm{l}$ drops were 
spotted in triplicate for each dilution on plates supplemented with appropriate antibiotics. The plates were incubated at $30^{\circ} \mathrm{C}$ for $48 \mathrm{~h}$ and colonies were counted in spots containing 1-30 colonies (Xu et al., 2008).

\section{Determination of ROS, and Lipid Peroxidation Content}

The $\mathrm{H}_{2} \mathrm{O}_{2}$ level was measured as described by Lee et al. (2007). To determine the $\mathrm{H}_{2} \mathrm{O}_{2}$ levels, the extracted solution was mixed with $0.1 \%$ titanium chloride in $20 \%(\mathrm{v} / \mathrm{v}) \mathrm{H}_{2} \mathrm{SO}_{4}$, and the mixture was then centrifuged at $10,000 \times g$ for $5 \mathrm{~min}$. The absorbance of the supernatant was measured at $410 \mathrm{~nm}$. The $\mathrm{H}_{2} \mathrm{O}_{2}$ level was calculated using the extinction coefficient of $0.28 \mu \mathrm{mol}^{-1} \mathrm{~cm}^{-1}$.

For the visualization in situ of superoxide anion radical $\left(\mathrm{O}_{2}^{\bullet-}\right)$, leaf discs were immersed in $0.1 \%$ solution of nitroblue tetrazolium (NBT) in K-phosphate buffer ( $\mathrm{pH} \mathrm{6.4),} \mathrm{containing}$ $10 \mathrm{mM} \mathrm{Na}$-azide, and were vacuum-infiltrated for $60 \mathrm{~min}$ and illuminated until the appearance of dark spots, characteristic of the blue formazan precipitate. After bleaching in boiling ethanol, the leaf samples were photographed under a light microscope (Leica DM4000; Leica, Wetzlar, Germany) at $40 \times$ magnifications (Muneer et al., 2013).

The lipid peroxidation level was determined by measuring the concentration of malondialdehyde (MDA), as described previously (Lee et al., 2007).

\section{Phytohormone Analysis}

Quantitative analysis of JA, SA, and ABA in the leaf tissue was performed according to Pan et al. (2010). JA, SA, and ABA extracts from $50 \mathrm{mg}$ of well-ground leaves were injected into a reverse phase $\mathrm{C} 18$ Gemini high-performance liquid chromatography (HPLC) column for HPLC-electrospray ionization tandem mass spectrometry (HPLC-ESI-MS/MS) analysis. Agilent 1100 HPLC (Agilent Technologies), Waters C18 column $(150 \times 2.1 \mathrm{~mm}, 5 \mu \mathrm{m})$, and API3000 MSMRM (Applied Biosystems) were used for the analysis.

\section{Determination of Defensive Metabolites in the Phenylpropanoid Pathways} Total Phenolic and Flavonoid Contents

Total phenolic content in the leaves was determined by the FolinCiocalteu reagent assay (Lee et al., 2007). Total phenolic content was expressed as milligrams of gallic acid per gram fresh weight (FW). Total flavonoid content was measured by the aluminum chloride colorimetric assay (Zhishen et al., 1999) as expressed by milligrams of quercetin per gram FW.

\section{Soluble and Insoluble Tannin Contents}

Soluble and insoluble tannin contents were spectrophotometrically determined by the F-D method (Bubba et al., 2009). To determine the soluble and insoluble tannin content in $3.1 \mathrm{ml}$ of ultrapure water, $0.1 \mathrm{ml}$ of the extract and $300 \mu \mathrm{l}$ of F-D reagent were added. After $3 \mathrm{~min}, 300 \mu \mathrm{l}$ of a saturated aqueous solution of sodium carbonate was added. The results are expressed as milligrams of gallic acid per gram FW.

\section{Proanthocyanidin and Total Hydroxycinnamic Acid (THA) Contents}

The total proanthocyanidin content was measured using the 4-dimethylaminocinnamaldehyde (DMAC) assay (Prior et al., 2010). Total proanthocyanidins were quantified as catechin equivalents using a catechin standard curve. Determination of total hydroxycinnamic acid (THA) was performed by colorimetric methods using the chromogenic system of $\mathrm{HCl}$ $\mathrm{NaNO}_{2}-\mathrm{Na}_{2} \mathrm{MoO}_{4}-\mathrm{NaOH}$ with chlorogenic acid standard (Štefan et al., 2014).

\section{Glutathione and NADPH Redox}

Total GSH and oxidized GSH (GSSG) were assayed using 5,5-dithiobisnitrobenzoic acid (DTNB), according to the method of Rahman et al. (2006). For the determination of total GSH, the test solution was prepared by taking $2 \mu \mathrm{l}$ of sample diluted with $31 \mu \mathrm{l}$ of $100 \mathrm{mM} \mathrm{K}-\mathrm{PO}_{4}$ buffer containing $6.3 \mathrm{mM}$ EDTA, then added with $140 \mu \mathrm{l}$ of NADPH $(0.248 \mathrm{mg} / \mathrm{ml})$ and $20 \mu \mathrm{l}$ of DTNB $(6 \mathrm{mM})$, followed by GSH reductase $(0.5 \mathrm{U})$. The absorbance was immediately recorded at $412 \mathrm{~nm}$ using a microplate reader, and measurements were taken every $1 \mathrm{~min}$ for $4 \mathrm{~min}$. The test solution for GSSG determination was prepared by taking $5 \mu \mathrm{l}$ of sample diluted with $28 \mu \mathrm{l}$ of $100 \mathrm{mM} \mathrm{K}-\mathrm{PO}_{4}$ buffer containing $6.3 \mathrm{mM}$ EDTA, then added $140 \mu \mathrm{l}$ of NADPH $(0.248 \mathrm{mg} / \mathrm{ml})$ and $20 \mu \mathrm{l}$ of DTNB $(6 \mathrm{mM})$, then GSH reductase $(0.5 \mathrm{U})$ was added. The absorbance was immediately recorded at $412 \mathrm{~nm}$ using a microplate reader, with measurements taken every $1 \mathrm{~min}$ for $4 \mathrm{~min}$. Reduced GSH and oxidized GSSG were quantified using respective standard curves and expressed as nanomoles per gram FW. The resulting reduced/oxidized GSH/GSSG ratio was calculated.

For the determination of NADPH and $\mathrm{NADP}^{+}$concentration, fresh leaf samples $(0.2 \mathrm{~g})$ were immediately homogenized with $0.8 \mathrm{ml}$ of $0.2 \mathrm{M} \mathrm{NaOH}$ for the NADPH assay and with $0.2 \mathrm{~N} \mathrm{HCl}$ for the $\mathrm{NADP}^{+}$assay. The supernatants following a centrifugation $12,000 \times g$ for $10 \mathrm{~min}$ at $4^{\circ} \mathrm{C}$ were heated at $95^{\circ} \mathrm{C}$ for $1 \mathrm{~min}$ and stopped in ice-bath. The supernatant for $\mathrm{NADP}^{+}$determination was adjusted to $\mathrm{pH} 5-6$ by $0.2 \mathrm{M}$ $\mathrm{NaOH}$ or to $\mathrm{pH} 7-8$ with $0.2 \mathrm{~N} \mathrm{HCl}$. The oxidized and reduced pyridine nucleotide contents were determined using the protocol of Queval and Noctor (2007).

\section{Isolation of Total RNA and Quantitative Real-Time PCR}

Total RNA was isolated from $200 \mathrm{mg}$ leaf tissue using the SV Total RNA Isolation System (Promega). First-strand cDNAs were synthesized using the GoScript Reverse Transcription System (Promega). The gene expression level was quantified on a light cycler real-time PCR detection system (Bio-Rad) with SYBR Premix Ex TaqTM (TaKaRa, DALIAN). The sequences of primers are presented in Supplementary Table S1. All the quantifications were normalized to ACTIN. The qRT-PCR reactions were performed in triplicates for each of the three independent samples. Quantification of the relative transcript level was performed using the $2^{-\Delta \Delta C_{\mathrm{t}}}$ method (Livak and Schmittgen, 2001). 

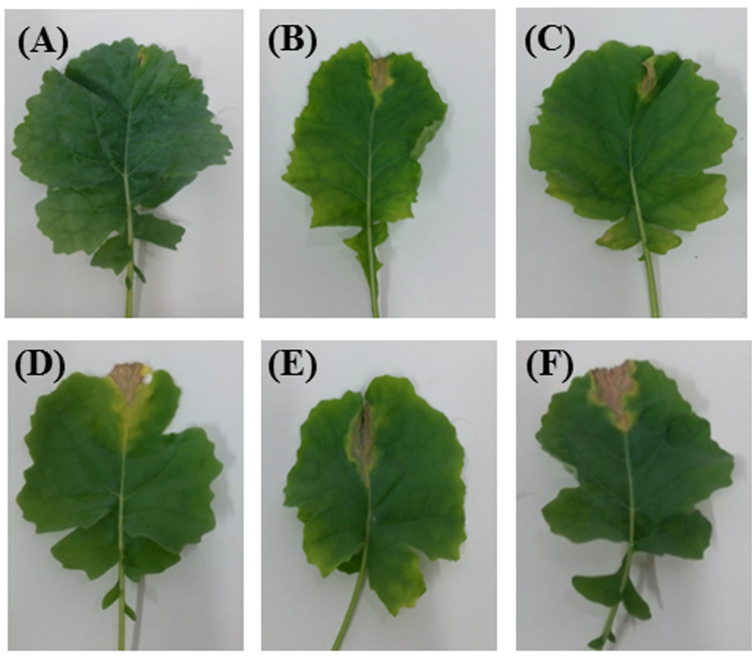

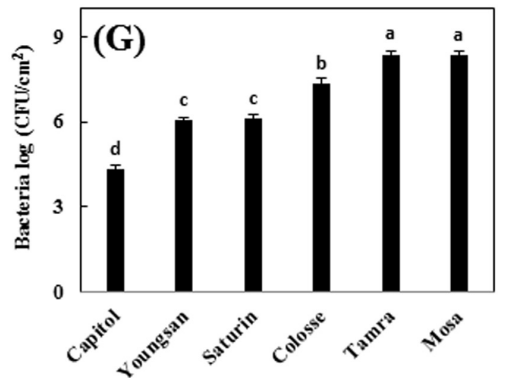

FIGURE 1 | Development of necrotic lesions in leaves of Brassica napus cultivars inoculated by Xanthomonas campestris pv. campestris (Xcc), which causes the black rot disease; (A) Capitol, (B) Youngsan, (C) Saturnin, (D) Colosse, (E) Tamra, and (F) Mosa. Bacterial populations in the inoculated areas were measured 14 days after inoculation and expressed as log of colony-forming units per square $\mathrm{cm}\left(\mathrm{cfu} / \mathrm{cm}^{2}\right)$. (G) Statistical groups were identified using Duncan's multiple range test. Different letters indicate significant differences at $P<0.05$.

\section{Statistical Analysis}

A completely randomized design was used with three replicates for six cultivars and two pathogen inoculation treatments. An individual pot containing three plants represented as a replicate. Student's $t$-test was employed to compare the means of separate replicates by using software SAS (version 9.1) (SAS Institute Inc., Cary, NC, United States). Different letter in tables indicates statistically significant difference at $P<0.05$. For principal component analysis (PCA) all biochemical defenses markers were considered in Xcc-inoculated plants of six different cultivars of $B$. napus. PCA analysis was performed using the Factor analysis and data mining with $\mathrm{R}$ (FactoMineR) package (Husson et al., 2008).

\section{RESULTS}

\section{Disease Symptoms, Bacterial Populations, and Oxidative Stress Development}

Xanthomonas campestris pv. campestris-inoculation induced $\mathrm{V}$-shaped necrosis in leaf margins. Among the six cultivars, cv. Capitol showed least symptoms (Figure 1A), whereas severe necrosis occurred in cvs. Colosse, Tamra, and Mosa (Figures 1D-F) and moderate symptoms were observed in cvs. Youngsan and Saturnin (Figures 1B,C). The lowest bacterial populations were measured in $\mathrm{cv}$. Capitol, while the highest bacterial populations were observed in cvs. Tamra and Mosa (Figure 1G).

Reactive oxygen species production was determined by visualizing superoxide anion radical $\left(\mathrm{O}_{2}^{\bullet-}\right)$ accumulation and quantifying hydrogen peroxide $\left(\mathrm{H}_{2} \mathrm{O}_{2}\right)$ content. Relatively higher accumulation of superoxide anion radical occurred in cvs.
Colosse, Tamra, and Mosa (Figure 2A). The increase in $\mathrm{H}_{2} \mathrm{O}_{2}$ content caused by Xcc-inoculation was also significant in cvs. Tamra $(+41 \%)$ and Mosa (+63\%) (Figure 2B). Significant increase in lipid peroxidation level, as determined by MDA content, was observed in cvs. Colosse $(+17 \%)$, Tamra $(+20 \%)$, and Mosa $(+72 \%)$. The lowest changes in ROS production and lipid peroxidation were observed in cv. Capitol (Figure 2).

\section{Phytohormone Contents}

Xanthomonas campestris pv. campestris-inoculation decreased the endogenous level of JA in all cultivars examined, with a reduction ranging from $-4.8 \%$ (cv. Capitol) to $-89.3 \%$ (cv. Mosa) compared with the non-pathogen inoculated control (Figure 3A). SA was significantly increased in all cultivars except cv. Capitol (Figure 3B). Similarly, ABA was also increased in all cultivars except cvs. Capitol and Saturin (Figure 3C). The resulting SA/JA and $\mathrm{ABA} / \mathrm{JA}$ ratios increased significantly in all cultivars examined, with the highest increase observed in cV. Mosa (33.1- and 14.0-fold, respectively) compared to the control (Figures 3D,E).

\section{Phytohormone-Signaling-Related Gene Expression}

The relative expression of a JA-responsive gene, Plant defensin 1.2 (PDF 1.2), was enhanced significantly by Xcc-inoculation only in cv. Capitol $(+56 \%)$. However, PDF 1.2 expression was depressed in cvs. Tamra (-53\%) and Mosa (-36\%) (Figure 4A). Expression of the transcriptional factor MYC2, an ABA-signaling regulatory gene, was significantly increased in cvs. Tamra $(+60 \%)$ and Mosa (+97\%) (Figure 4B). The SA-regulated gene NPR1 was upregulated in cvs. Colosse $(+94 \%)$, Mosa $(+120 \%)$, and Tamra $(+121 \%)$ (Figure 4C). Similarly, expression of the transcriptional factor TGA1, which also regulates the 


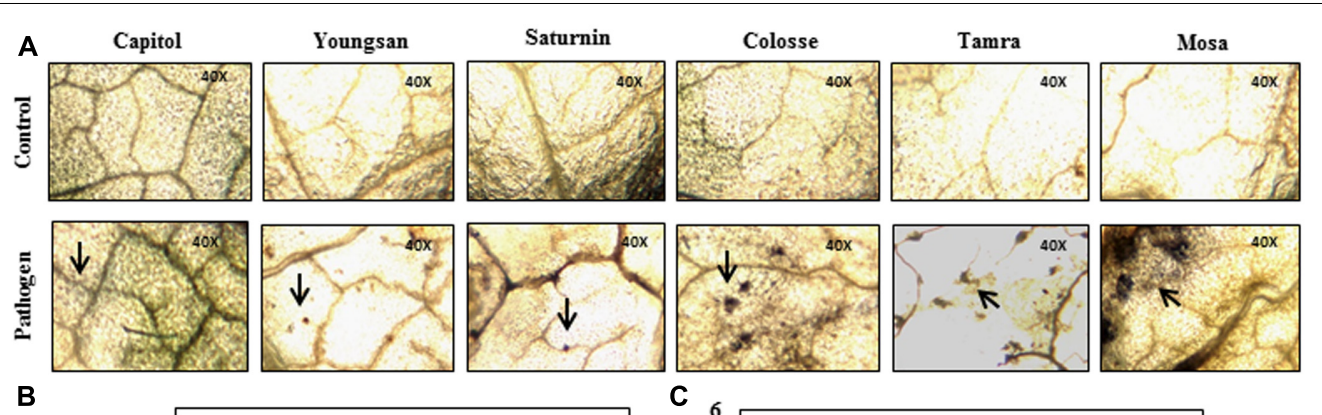

B
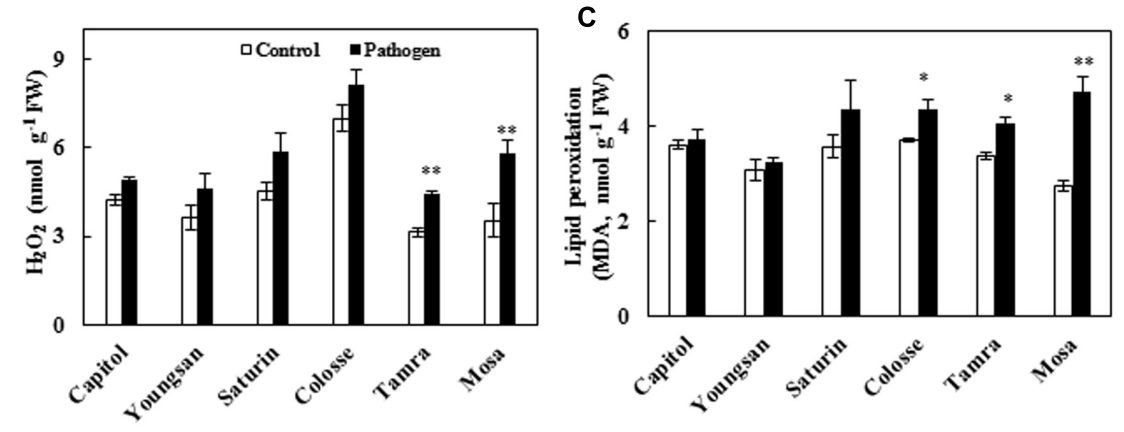

FIGURE 2 | Oxidative stress development in control (open bar) and $X$. campestris pv. campestris (Xcc) inoculated (filled bar) leaves of six B. napus cultivars; (A) Superoxide anion radical $\left(\mathrm{O}_{2}^{-}\right)$accumulation visualized by nitroblue tetrazolium (NBT) staining, (B) hydrogen peroxide $\left(\mathrm{H}_{2} \mathrm{O}_{2}\right)$, and (C) lipid peroxidation (malondialdehyde, MDA). Data are presented as means \pm SE for $n=3$. Asterisks indicate significant differences between the control and pathogen-stressed plants; ${ }^{*} P<0.05,{ }^{* *} P<0.01,{ }^{* * *} P<0.001$
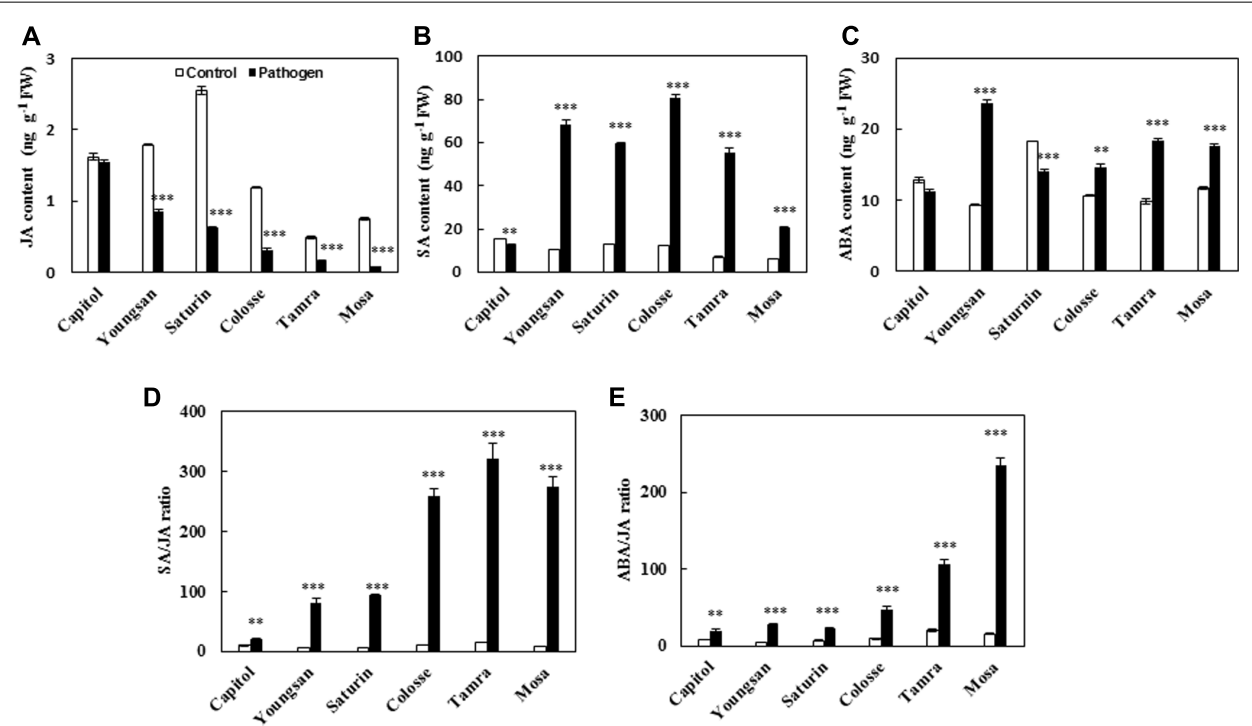

FIGURE 3 | Phytohormonal changes in response to $X$. campestris pv. campestris (Xcc) inoculation in six different B. napus cultivars; (A) Jasmonic acid (JA), (B) salicylic acid (SA), (C) abscisic acid (ABA), (D) ratio of SA/JA, and (E) ratio of ABA/JA. Data are presented as means \pm SE for $n=3$. Asterisks indicate significant differences between the control and pathogen-stressed plants; ${ }^{*} P<0.05$, ${ }^{* *} P<0.01,{ }^{* * *} P<0.001$.

SA-signaling pathway, was enhanced in cvs. Tamra $(+139 \%)$ and Mosa $(+112 \%)$, while depressed in cv. Capitol $(-44 \%)$ (Figure 4D).

\section{NADPH and Glutathione Redox Status}

Xanthomonas campestris pv. campestris-inoculation significantly increased $\mathrm{NADP}^{+}$concentration in all cultivars except cv.
Capitol (Figure 5A). A significant increase in NADPH concentration was observed only in cv. Capitol $(+76 \%)$, but a decrease was observed in cv. Mosa (-40\%) (Figure 5B). The resulting NADPH/NADP ${ }^{+}$ratio was significantly increased by Xcc-inoculation in cv. Capitol, while it was decreased more distinctly in cvs. Tamra $(-63.0 \%)$ and Mosa $(-64.7 \%)$ (Figure 5C). 

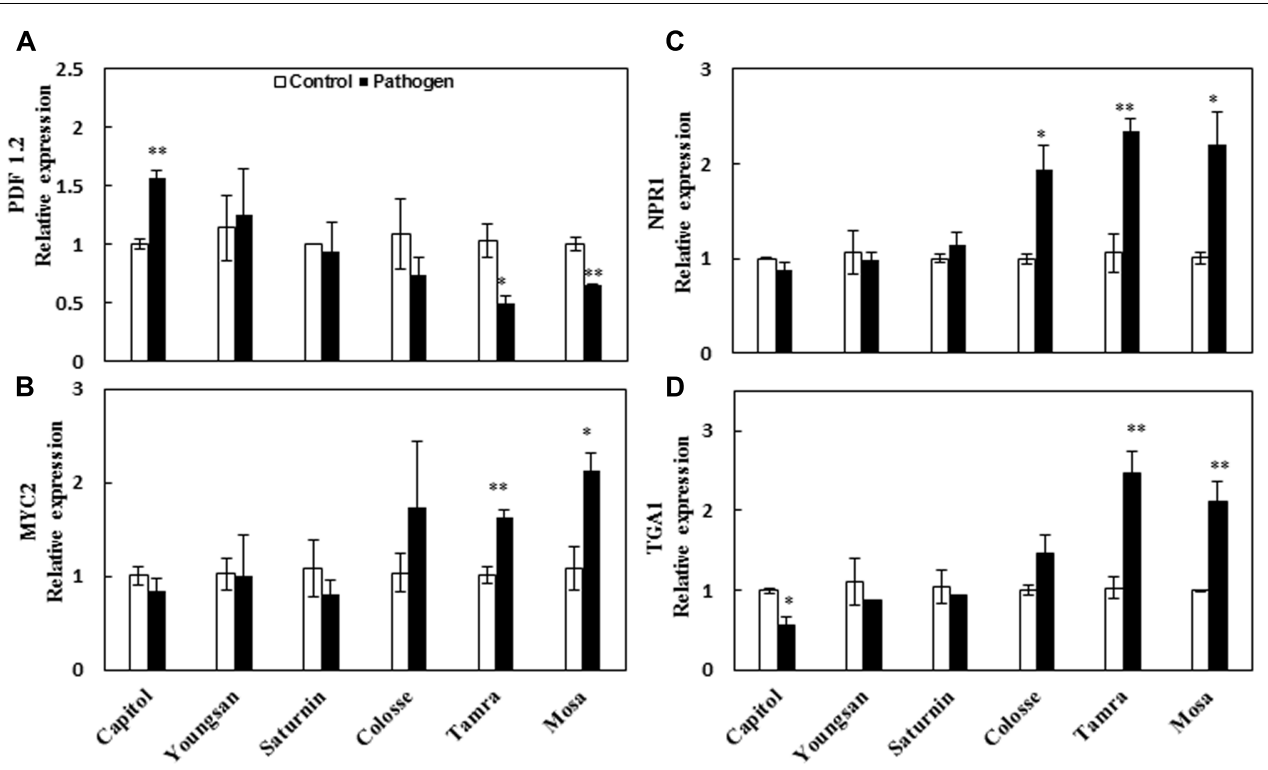

FIGURE 4 | Relative expression of phytohormone-signaling regulated genes in the control (open bar) and X. campestris pv. campestris (Xcc) inoculated (filled bar) leaves of six different B. napus cultivars. (A) Jasmonic acid-regulated gene PDF 1.2, (B) ABA-regulated gene MYC2, (C) salicylic acid-regulated gene NPR1, and (D) TGA1. Data are presented as means \pm SE for $n=3$. Asterisks indicate significant differences between the control and pathogen-stressed plants; ${ }^{*}<0.05$, **P $<0.01,{ }^{* * *} P<0.001$.
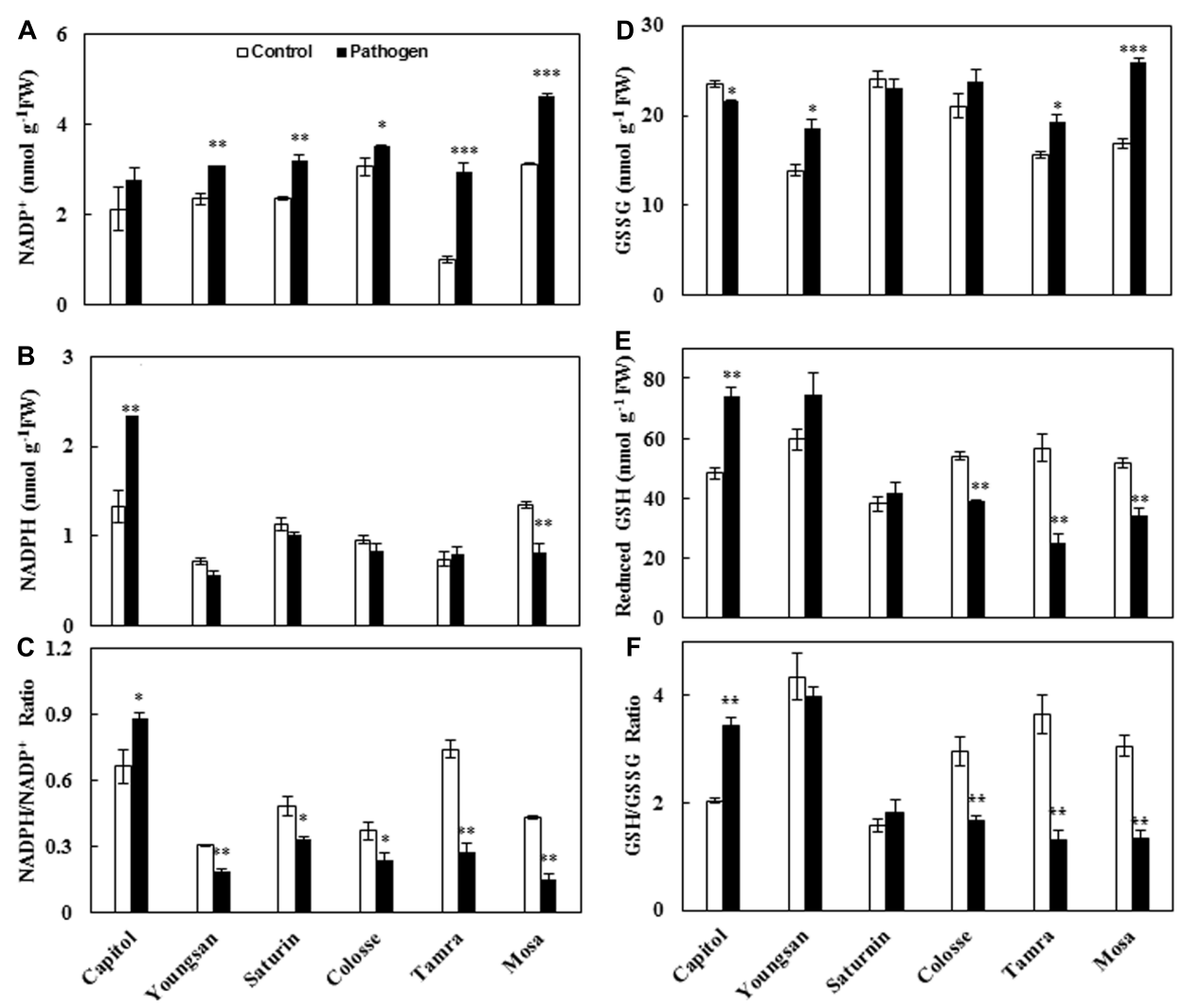

FIGURE 5 | Glutathione and NADPH redox responses to $X$. campestris pv. campestris (Xcc) inoculation in six different B. napus cultivars: (A) NADP+, (B) NADPH, (C) the NADP ${ }^{+} / \mathrm{NADPH}$ ratio, (D) oxidized glutathione (GSSG), (E) reduced glutathione (GSH) content, and (F) the ratio of GSH to GSSG. Data are presented as means \pm SE for $n=3$. Asterisks indicate significant differences between the control and pathogen-stressed plants; ${ }^{*} P<0.05$, ${ }^{* *} P<0.01$, ${ }^{* * *} P<0.001$. 
Similarly, the oxidized GSH, GSH disulfide (GSSG), was significantly increased in cvs. Tamra $(+23 \%)$ and Mosa $(+53 \%)$, while it was decreased in cv. Capitol $(-6.3 \%)$ (Figure 5D). Opposite responses to Xcc-inoculation were observed for reduced GSH content (Figure 5E). The resulting reduced/oxidized GSH/GSSG ratio increased in cv. Capitol $(+68 \%)$, whereas it significantly decreased in cvs. Colosse $(-44 \%)$, Tamra $(-72 \%)$, and Mosa $(-36 \%)$ (Figure 5F).

\section{Contents of Defensive Metabolites of Phenylpropanoid Pathway}

In cv. Capitol, Xcc-inoculation significantly increased total phenolic $(+18.7 \%)$, flavonoids $(+18.5 \%)$, total tannin $(+32.3 \%)$, proanthocyanidin $(90.5 \%)$, and THA $(+29.7 \%)$, whereas these phenolic compounds were not significantly changed or slightly decreased in other cultivars. The overall content of these compounds in Xcc-inoculated plants was higher in cv. Capitol compared with other cultivars (Table 1).

\section{Gene Expression Involved in Phenylpropanoid Pathway}

To compare cultivar variation in polyphenol biosynthesis in response to Xcc-inoculation, relative expression of three major genes of the phenylpropanoid pathway [chalcone synthase $(C H S)$, anthocyanidin reductase $(A N R)$, and ferulate5-hydroxylase $(F 5 H)$ that regulate the synthesis of flavonoids, proanthocyanidins, and hydroxycinnamic acids, respectively] was evaluated. Xcc-inoculation significantly enhanced the expression of CHS (4.1-fold), ANR (1.9-fold), and F5H (2.1-fold) genes in cv. Capitol, whereas the expression of these genes was significantly depressed or not changed in other cultivars (Figures 6A-C).

\section{Principal Component Analysis}

Principal component analysis was applied to detect any possible clusters with respect to the responses of physiological and defensive parameters to Xcc-inoculation in six different cultivars (Figure 7). The cumulative contribution of the first and the second principal components attained $71.3 \%$. Principal component 1 (PCA1) explained up to $48.4 \%$ of the total variance and principal component 2 (PCA2) explained $22.9 \%$ of the variation. PCA1 was highly contributed by JA (0.99), PDF 1.2 (0.96), NPR1 (-0.90), TGA1 (-0.89), MYC2 (-0.84), SA/JA ratio $(-0.93), \mathrm{ABA} / \mathrm{JA}$ ratio $(-0.74), \mathrm{MDA}(-0.61), \mathrm{GSH} / \mathrm{GSSG}$ ratio (0.78), $\mathrm{NADP}^{+} / \mathrm{NADPH}$ ratio (0.84), proanthocyanidins $(0.70)$, THA (0.74), insoluble tannin (0.57), CHS (0.89), ANR (0.94), and F5H (0.85). The second PCA separated the samples on the basis of soluble tannin (0.91), insoluble tannin (0.57), flavonoids (0.69), total phenolics (0.86), SA (-0.58), ABA (-0.65), and NADPH (0.54) values. Notably, all parameters of cv. Capitol were clustered into one group as they had highly positive correlation with PCA1 and PCA2, whereas cvs. parameters of cultivars Youngsan and Saturnin were clustered into another group as they had a positive correlation with PCA1 and a higher negative correlation with PCA2. Parameters of cvs. Colosse, Tamra, and Mosa were also clustered into another group; they had a negative correlation with PCA1.

\section{DISCUSSION}

Accumulation of ROS, such as $\mathrm{O}_{2}^{\bullet-}, \mathrm{H}_{2} \mathrm{O}_{2}$, and hydroxyl radical, and the induction of their scavenging enzymes are basic responses to plant stresses caused by a wide range of environmental stresses (Lee et al., 2009) and pathogen infection (Silva et al., 2004; Finiti et al., 2014). The dynamic balance between ROS and scavenging enzymes might be disturbed under a stressed condition. Rapid production of ROS leading oxidative burst is described as one of the earliest plant responses to pathogen infection. Due to the impairment of ROS-scavenging system, enhanced lipid peroxidation (MDA) occurs, which is associated with necrosis of plant tissues (Venisse et al., 2001). We previously defined cultivar variation in drought tolerance

TABLE 1 | Changes in the contents of phenylpropanoid compounds as affected by Xanthomonas campestris pv. campestris (Xcc) inoculation in six different Brassica napus cultivars.

\begin{tabular}{|c|c|c|c|c|c|c|c|}
\hline \multirow{2}{*}{$\begin{array}{l}\text { Secondary metabolite } \\
\text { content (mg g } \\
-1\end{array}$} & \multirow[t]{2}{*}{ Treatment } & \multicolumn{6}{|c|}{ Different cultivar of $B$. napus } \\
\hline & & Capitol & Youngsan & Saturin & Colosse & Tamra & Mosa \\
\hline \multirow[t]{2}{*}{ Total phenolic } & Control & $0.91 \pm 0.03^{b}$ & $0.88 \pm 0.03^{b}$ & $0.95 \pm 0.06^{a}$ & $1.00 \pm 0.04^{a}$ & $0.96 \pm 0.03^{a}$ & $0.97 \pm 0.01^{a}$ \\
\hline & Xcc & $1.08 \pm 0.04^{a}$ & $0.96 \pm 0.01^{a}$ & $0.89 \pm 0.03^{a}$ & $1.14 \pm 0.05^{a}$ & $1.01 \pm 0.02^{a}$ & $1.09 \pm 0.05^{a}$ \\
\hline \multirow[t]{2}{*}{ Total flavonoids } & Control & $4.65 \pm 0.15^{b}$ & $4.10 \pm 0.32^{a}$ & $4.69 \pm 0.58^{a}$ & $5.26 \pm 0.27^{a}$ & $5.21 \pm 0.06^{a}$ & $4.34 \pm 0.29^{a}$ \\
\hline & Xcc & $5.51 \pm 0.18^{a}$ & $4.99 \pm 0.59^{a}$ & $4.27 \pm 0.32^{a}$ & $5.78 \pm 0.61^{a}$ & $5.49 \pm 0.20^{a}$ & $5.34 \pm 0.26^{a}$ \\
\hline \multirow[t]{2}{*}{ Soluble tannin } & Control & $0.74 \pm 0.02^{b}$ & $0.75 \pm 0.01^{b}$ & $0.72 \pm 0.01^{a}$ & $0.77 \pm 0.01^{a}$ & $0.88 \pm 0.01^{a}$ & $0.80 \pm 0.01^{a}$ \\
\hline & $X_{c c}$ & $0.89 \pm 0.04^{a}$ & $0.79 \pm 0.01^{a}$ & $0.76 \pm 0.03^{a}$ & $0.87 \pm 0.10^{a}$ & $0.84 \pm 0.01^{b}$ & $0.86 \pm 0.03^{a}$ \\
\hline \multirow[t]{2}{*}{ Insoluble tannin } & Control & $3.61 \pm 0.29^{b}$ & $3.95 \pm 0.29^{a}$ & $3.79 \pm 0.01^{a}$ & $3.54 \pm 0.32^{a}$ & $3.40 \pm 0.16^{a}$ & $4.39 \pm 0.23^{a}$ \\
\hline & $X_{c c}$ & $5.22 \pm 0.23^{a}$ & $4.05 \pm 0.17^{a}$ & $4.21 \pm 0.53^{a}$ & $4.05 \pm 0.18^{a}$ & $3.43 \pm 0.20^{a}$ & $4.82 \pm 0.27^{a}$ \\
\hline \multirow[t]{2}{*}{ Proanthocyanidin } & Control & $1.26 \pm 0.10^{b}$ & $1.75 \pm 0.39^{a}$ & $1.98 \pm 0.33^{a}$ & $1.68 \pm 0.43^{a}$ & $1.83 \pm 0.10^{a}$ & $2.19 \pm 0.01^{a}$ \\
\hline & Xcc & $2.40 \pm 0.25^{a}$ & $2.41 \pm 0.17^{a}$ & $2.08 \pm 0.35^{a}$ & $1.60 \pm 0.29^{a}$ & $1.12 \pm 0.23^{b}$ & $2.03 \pm 0.35^{a}$ \\
\hline \multirow[t]{2}{*}{ Total hydroxycinnamic acid } & Control & $0.64 \pm 0.03^{b}$ & $0.61 \pm 0.01^{a}$ & $0.62 \pm 0.02^{a}$ & $0.64 \pm 0.11^{a}$ & $0.62 \pm 0.07^{a}$ & $0.55 \pm 0.01^{a}$ \\
\hline & $X_{c c}$ & $0.83 \pm 0.04^{a}$ & $0.65 \pm 0.02^{a}$ & $0.62 \pm 0.12^{a}$ & $0.76 \pm 0.04^{a}$ & $0.72 \pm 0.03^{a}$ & $0.52 \pm 0.04^{a}$ \\
\hline
\end{tabular}

Values are means of three biological replicates. Different letters in a vertical column indicate significant difference at $P<0.05$. 


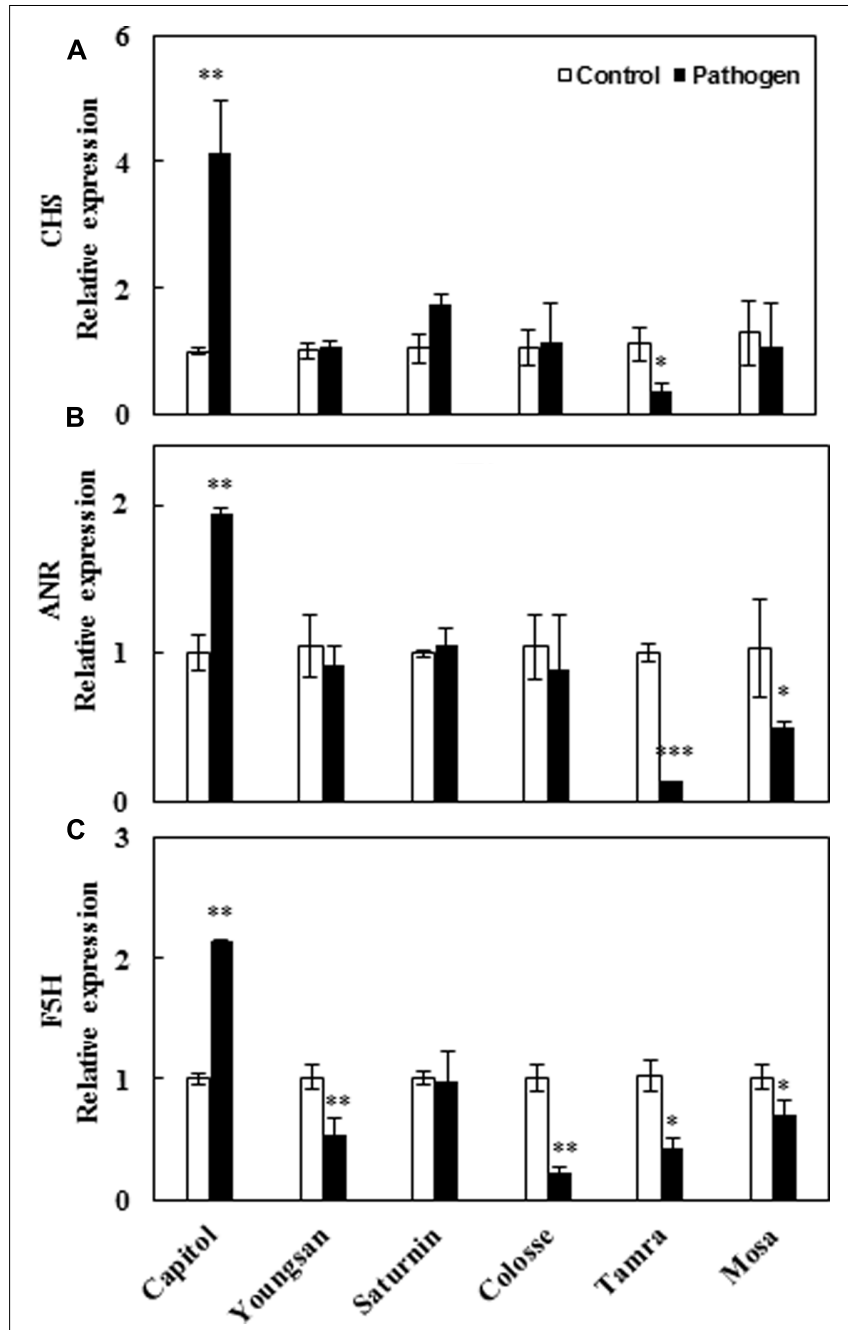

FIGURE 6 | Relative expression of genes involved in phenylpropanoid synthesis pathway in control (open bar) and $X$. campestris pv. campestris (Xcc) inoculated (filled bar) leaves of six different $B$. napus cultivars:

(A) Chalchon synthase, (B) anthocyanidin reductase, and

(C) ferulate-5-hydroxylase. Data are presented as means \pm SE for $n=3$. Asterisks indicate significant differences between the control and pathogen-stressed plants; ${ }^{*} P<0.05,{ }^{*} P<0.01,{ }^{* * *} P<0.001$.

with regard to $\mathrm{N}$ use efficiency for $\mathrm{N}$ uptake and de novo protein synthesis (Lee et al., 2015), and sulfur (S) use efficiency in relation to photosynthetic activity (Lee et al., 2016) in B. napus cultivars. We suggested that cultivar differences in pathogen resistance exist. Therefore, in the present study, we elucidated in vivo regulation of the pathogen resistance mechanism. As expected, cultivar variation in disease symptom development, ROS production, and lipid peroxidation was observed following Xcc-inoculation. Varietal differences in the V-shaped necrotic lesion area and higher bacterial population (Figure 1) were characterized by the increased ROS accumulation and lipid peroxidation level upon Xcc-inoculation (Figure 2), which can be classified into three groups: the most symptomless, resistant (cv. Capitol), moderate (cvs. Youngsan, Saturnin, and Colosse), and susceptible (cvs. Tamra and Mosa). Elevated ROS level not only alters transcription of genes and metabolic pathway, but also is involved in the biosynthesis and functioning of phytohormones (Choudhury et al., 2017). A complex interplay between ROS and phytohormones has been recently elucidated under abiotic stress: ROS and auxin-mediated signaling (Xia et al., 2015), ABAdependent ROS production (Zhou et al., 2014; Xia et al., 2015), and SA interaction with ROS (Herrera-Vásquez et al., 2015).

For hormonal regulation in the host plant-pathogen interaction, SA-dependent signaling is activated by biotrophic pathogens while JA-dependent signaling is activated by necrotrophic pathogens and leaf-chewing insects (Pieterse et al., 2009) for induction of plant defenses. Antagonistic hormonal interaction is involved in regulating defense responses (Anderson et al., 2004; Martínez-Medina et al., 2017). Among the six phytohormones analyzed in the present study, cultivar variation and Xcc-inoculation effects were significant only in JA, SA, and ABA levels. Overall Xcc-inoculation depressed JA level (Figure 3A), but enhanced SA level (except in cv. Capitol; Figure 3B) and ABA level (except in cvs. Capitol and Saturnin; Figure 3C). The SA/JA and ABA/JA ratios altered by Xcc-inoculation reflected cultivar variation in disease symptom development and ROS status, as shown by the lowest increase in both hormonal balances in cv. Capitol (the most symptomless cultivar) (Figures 3D,E) with enhanced expression of JA-regulated gene PDF 1.2 (Figure 4A), but more distinct increases in the ratios with higher enhancement of MYC2, NPR1, and TGA1 gene expressions in cvs. Tamra and Mosa (susceptible cultivars) (Figures 4B-D). These results indicate that JA-based resistance as well as SA- and/or ABA-associated susceptible responses occurred in $B$. napus-Xcc interaction. However, in the SA-deficient mutant (NahG) of Arabidopsis, severe necrosis with JA accumulation was observed $48 \mathrm{~h}$ after Xcc inoculation (O'Donnell et al., 2003). ABA application also showed more rapid proliferation of Xcc in Arabidopsis (Ho et al., 2013). The discrepancy of SA- and JA-dependent responses in $B$. napus (Figures 3A,B) and Arabidopsis, that needs to be elucidated further, might be associated with the differences in the necrotrophic phase and susceptibility to Xcc infection between the two host plants. Similarly, the lower JA level in JA-insensitive coi1-1 mutants of Arabidopsis was responsible for susceptibility to the pathogen Pythium irregulare (Adie et al., 2007), and higher SA level was found in wheat mutants susceptible to F. graminearum in the later stage of infection (Ding et al., 2011). Martínez-Medina et al. (2017) have recently reported that shifting from priming of SA- to JA-regulated defenses induced resistance to root-knot nematode in tomato.

To investigate whether the alteration of JA-based hormonal balance by Xcc-inoculation, which reflected cultivar variation in disease symptom development, is a significant regulating factor of disease tolerance, we estimated the responses of redox status, defensive metabolites, and expression of genes involved in the phenylpropanoid synthesis pathway. NADPH is characterized as a cofactor in proline biosynthesis (Shinde et al., 2016), which is enhanced under stress conditions (Kim et al., 2004; Lee et al., 2013). NADPH concentration was significantly $(P<0.01)$ increased by Xcc-inoculation in cv. Capitol, while 


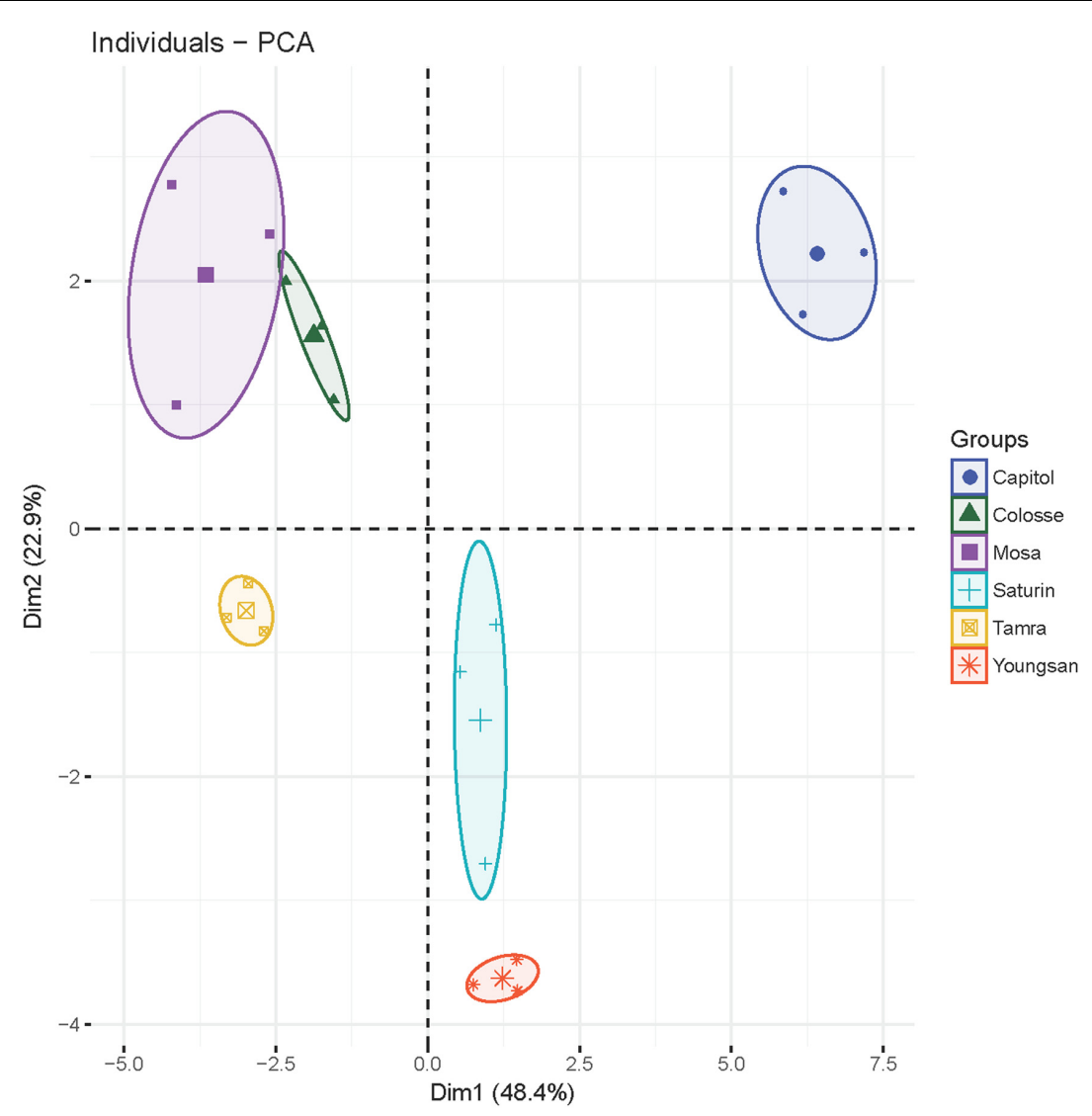

FIGURE 7 | The plot of principal component analysis for $X$. campestris pv. campestris (Xcc)-inoculation-responsive changes of physiological and defensive parameters in six different $B$. napus cultivars.

TABLE 2 | Linear relationships between descriptive parameters of hormonal status [jasmonic acid (JA), abscisic acid (ABA), and salicylic acid (SA) signaling gene expressions and JA-based hormone ratio] and defense responses (redox and phenylpropanoid synthesis-related genes) as affected by Xanthomonas campestris pv. campestris $\left(X_{c c}\right)$ inoculation in six different cultivars of $B$. napus.

\begin{tabular}{|c|c|c|c|c|c|}
\hline & GSH/GSSG & NADPH/NADP ${ }^{+}$ & $\mathrm{CHS}$ & ANR & $\mathrm{F} 5 \mathrm{H}$ \\
\hline MYC2 & $r=-0.418$ & $r=-0.421$ & $r=-0.292$ & $r=-0.289$ & $r=-0.398$ \\
\hline TGA1 & $r=-0.695^{* * *}$ & $r=-0.511^{*}$ & $r=-0.547^{*}$ & $r=-0.734^{* * *}$ & $r=-0.593^{* *}$ \\
\hline SA/JA & $r=-0.792^{* * *}$ & $r=-0.609^{* *}$ & $r=-0.654^{* *}$ & $r=-0.774^{* * *}$ & $r=-0.702^{* * *}$ \\
\hline ABA/JA & $r=-0.582^{* *}$ & $r=-0.478^{*}$ & $r=-0.403$ & $r=-0.649^{* *}$ & $r=-0.330$ \\
\hline
\end{tabular}

Asterisks indicate significant differences; ${ }^{*} P<0.05,{ }^{* *} P<0.01,{ }^{* * *} P<0.001$

it was decreased in cv. Mosa (Figure 5B). The resulting ratio of $\mathrm{NADPH} / \mathrm{NADP}^{+}$was significantly increased only in $\mathrm{cv}$. Capitol, while it was decreased in other five cultivars with the highest reduction in cvs. Tamra and Mosa (Figure 5C). GSH is an important non-enzymatic antioxidant in plant cells (Foyer and Noctor, 2011). Intracellular GSH redox homeostasis is accomplished by reducing the cellular disulphide bonds with a high intracellular concentration of GSH leading to an increase in GSH/GSSG ratio (Apel and Hirt, 2004). In the present study, Xcc-inoculation significantly $(P<0.01)$ enhanced GSH concentration in cv. Capitol, while decreased in cvs. Tamra and
Mosa (Figure 5E). The resulting reduced/oxidized GSH/GSSG ratio showed the same pattern with GSH response to Xccinoculation (Figure 5F). The results of the present study suggest that $\mathrm{NADP}^{+}$and the oxidized GSH form (GSSG) increased relatively higher in susceptible cultivars (cvs. Tamra and Mosa), leading to lower NADPH/NADP ${ }^{+}$and GSH/GSSG ratios, which reflects an oxidized status. This agrees with cultivar variation in oxidative burst in relation to the alteration of SA/JA and $\mathrm{ABA} / \mathrm{JA}$ ratios, which occurred in response to Xcc-inoculation. It thus concludes that the alteration of SA/JA and ABA/JA ratios is a defense response in alleviating oxidative imbalance caused 
by Xcc-infection. Indeed, we found that SA/JA and ABA/JA ratios were closely related $(P<0.01)$ with GSH/GSSG and $\mathrm{NADPH} \mathrm{NADP}^{+}$ratios, respectively, in Xcc-inoculated plants of the six cultivars (Table 2). Similarly, hexanoic acid-induced GSH/GSSG alteration was an earlier defense response to reduce oxidative stress against Botrytis cinerea (Finiti et al., 2014) and reduced GSH/GSSG ratio was responsible for susceptibility to B. cinerea in tomato (Kuźniak and Sklodowska, 2005).

Secondary metabolites that can be produced by various routes are involved in plant disease resistance (Iriti et al., 2005; Gunnaiah et al., 2012; Pieterse et al., 2012; Velasco et al., 2013). The results of the present study showed further accumulation of defensive metabolites of the phenylpropanoid pathway, such as flavonoids, hydroxycinnamic acids, and total phenolics in Xcc-inoculated plants of cv. Capitol (Table 1). However, these compounds were not changed or decreased in cvs. Tamra and Mosa. This indicates an alleviating effect of phenylpropanoid accumulation on resistance to Xcc in B. napus cultivars. Similarly, accumulation of glucosinolates and polyphenols (hydroxycinnamic acids and flavonoids) enhanced the resistance of B. rapa to Xcc (Velasco et al., 2013). In another study, resistance of wheat against $F$. graminearum was attributed to enhanced level of hydroxycinnamic acid amides, phenolic glucosides, and flavonoids (Gunnaiah et al., 2012). In addition, accumulation of proanthocyanidin conferred resistance against gray mold caused by B. cinerea in grapevine (Iriti et al., 2005).

We further interpreted the responses of genes involved in the phenylpropanoid synthesis pathway in relation to JA-based hormonal balance altered by Xcc-inoculation, which reflected cultivar variation in disease symptom development. The genes, $\mathrm{CHS}, \mathrm{F} 5 \mathrm{H}$, and $A N R$, are involved in the biosynthetic pathways of flavonoids, hydroxycinnamic acids, and proanthocyanidins, respectively (Fornalé et al., 2015). In the present study, Xccinoculation significantly $(P<0.01)$ enhanced the expression of these three genes in cv. Capitol, while it depressed or did not affect their expression in cvs. Tamra and Mosa (Figure 6), showing a reversed pattern and cultivar variation in disease symptoms (Figure 1) and ROS production (Figure 2). To elucidate whether the altered hormonal status by Xcc-inoculation is involved in susceptibility and resistance responses to Xccinoculation, correlations among the expression of these three genes and of JA-, ABA-, and SA-regulated genes were analyzed. The JA-regulated gene $P D F 1.2$ was positively correlated with the expression of CHS $(P<0.05), A N R(P<0.001)$, and $F 5 H$ $(P<0.01)$ genes, respectively (Table 2$)$. This indicates that the highest JA level (Figure 3A) with enhanced PDF 1.2 expression (Figure 4A) was a positive regulator of phenylpropanoid synthesis, resulting in elevated resistance in cultivar Capitol, but conversely in susceptibility in cultivars Tamra and Mosa. The JA signaling pathway regulates resistance against necrotrophic and hemibiotrophic pathogens by up-regulating the ERF branch marker gene PDF 1.2 (Berrocal-Lobo et al., 2002). In the present study, the SA signaling regulatory gene Non-expresor $P R \quad 1$ (NPR1) and the transcriptional factor TGA1 were up-regulated along with $M Y C 2$, a positive regulator of the ABA signaling pathway in susceptible cultivars (cvs. Tamra and Mosa) (Figure 4), with concurrent suppression of phenylpropanoid synthesis-related genes (Figure 6). Susceptible mutants of wheat to the hemibiotroph F. graminearum had higher SA content compared with the resistant genotype in the later stage of infection (Ding et al., 2011). Indeed, the SA signaling regulatory gene NPR1 and transcriptional factor TGA1 were negatively correlated with the expression of phenylpropanoid synthesisrelated genes (Table 2). These results indicate activation of the SA-regulated defense signal with enhanced expression of NPR1 and TGA in cvs. Tamra and Mosa (Figures 4C,D), and suppression of expression of the JA signaling pathway (Pieterse et al., 2012), leading to susceptibility to Xcc infection. Similarly, Spoel et al. (2007) reported that induction of the SA-signaling pathway by inoculation of avirulent $P$. syringae suppressed the JA signaling, rendering Arabidopsis susceptible to the necrotrophic fungus Alternaria brassicola. The present study also showed that enhanced alteration of the SA/JA ratio was responsible for susceptibility to Xcc infection (Figure 3D) in accordance with cultivar variation in symptom development (Figure 1) and ROS accumulation (Figure 2). Highly significant correlations between the SA/JA ratio with redox status [GSH/GSSG $(P<0.001)$ and NADPH/NADP ${ }^{+}(P<0.01)$ ratios] and the expression of phenylpropanoid synthesis-related genes [CHS $(P<0.01), A N R$ $(P<0.001)$, and F5H $(P<0.01)]$ were observed (Table 2$)$. In addition, PCA showed that $\mathrm{cv}$. Capitol was positively correlated with PCA1 and PCA2 which were determined by JA-based hormonal balance, PDF1.2 expression, phenolic metabolites, genes involved in the phenylpropanoid synthesis pathway, and the redox status.

Taken together, the results of the present study suggest that cultivar variation in disease susceptibility to Xcc-infection was determined by enhanced alteration of the SA/JA ratio, as a negative regulator of redox status and phenylpropanoid synthesis. To the best of our knowledge, the present study is the first to directly elucidate the physiological significance of hormonal balance in disease defense mechanisms, with regard to cultivar variation in disease susceptibility, especially in an economically important crop, B. napus.

\section{AUTHOR CONTRIBUTIONS}

MTI and T-HK designed the experiment and wrote the manuscript. MTI and B-RL carried out the experiment. T-HK, B-RL, S-HP, VHL, and D-WB participated in data interpretation and critical reading of the manuscript.

\section{FUNDING}

This work was supported by a grant from the National Research Foundation of South Korea (NRF-2017R1A2B4002914).

\section{SUPPLEMENTARY MATERIAL}

The Supplementary Material for this article can be found online at: https://www.frontiersin.org/articles/10.3389/fpls.2017.02121/ full\#supplementary-material 


\section{REFERENCES}

Adie, B. A. T., Pérez-Pérez, J., Pérez-Pérez, M. M., Godoy, M., SánchezSerrano, J., Schmelz, E. A., et al. (2007). ABA is an essential signal for plant resistance to pathogens affecting JA biosynthesis and the activation of defenses in Arabidopsis. Plant Cell 19, 1665-1681. doi: 10.1105/tpc.106. 048041

Aires, A., Dias, C. S. P., Carvalho, R., Oliveira, M. H., Monteiro, A. A., Simoes, M. V., et al. (2011). Correlations between disease severity, glucosinolate profiles and total phenolics and Xanthomonas campestris pv. campestris inoculation of different Brassicaceae. Sci. Hortic. 129, 503-510. doi: 10.1016/j.scienta.2011. 04.009

Anderson, J. P., Badruzsaufari, E., Schenk, P. M., Manners, J. M., Desmond, O. J., Ehlert, C., et al. (2004). Antagonistic interaction between abscisic acid and jasmonate-ethylene signaling pathways modulates defense gene expression and disease resistance in Arabidopsis. Plant Cell 16, 3460-3479. doi: 10.1105/tpc. 104.025833

Apel, K., and Hirt, H. (2004). Reactive oxygen species: metabolism, oxidative stress, and signal transduction. Annu. Rev. Plant Biol. 55, 373-399. doi: 10.1146/ annurev.arplant.55.031903.141701

Barman, A. R., Kamei, A., and Dutta, S. (2015). Defence-related enzymatic response in cabbage to Xanthomonas campestris pv. campestris. Arch. Phytopathol. Plant Prot. 48, 9-12.

Berrocal-Lobo, M., Molina, A., and Solano, R. (2002). Constitutive expression of ETHYLENE-RESPONSE FACTOR1 in Arabidopsis confers resistance to several necrotrophic fungi. Plant J. 29, 23-32. doi: 10.1046/j.1365-313x.2002.01191.x

Bubba, M. D., Giordani, E., Pippucci, L., Cincinelli, A., Checchini, L., and Galvan, P. (2009). Changes in tannins, ascorbic acid and sugar content in astringent persimmons during on-tree growth and ripening and in response to different postharvest treatments. J. Food Comp. Anal. 22, 668-677. doi: 10.1016/j.jfca.2009.02.015

Buell, C. R. (2002). Interactions between Xanthomonas Species and Arabidopsis thaliana. Arabidopsis Book 1:e0031.

Choudhury, F. K., Rivero, R. M., Blumwald, E., and Mittler, R. (2017). Reactive oxygen species, abiotic stress and stress combination. Plant J. 90, 856-867. doi: $10.1111 /$ tpj.13299

Ding, L., Xu, H., Yi, H., Yang, L., Kong, Z., Zhang, L., et al. (2011). Resistance to Hemi-biotrophic F. graminearum infection is associated with coordinated and ordered expression of diverse defense signaling pathways. PLOS ONE 6:e19008. doi: 10.1371/journal.pone.0019008

Finiti, I., Leyva, M. O., Vicedo, B., Gómez-pastor, R., López-cruz, J., Garcíaagustín, P., et al. (2014). Hexanoic acid protects tomato plants against Botrytis cinerea by priming defense responses and reducing oxidative stress. Mol. Plant Pathol. 15, 550-562. doi: 10.1111/mpp.12112

Fornalé, S., Rencoret, J., Garcia-Calvo, L., Capellades, M., Encina, A., Santiago, R., et al. (2015). Cell wall modifications triggered by the down-regulation of Coumarate 3-hydroxylase-1 in maize. Plant Sci. 236, 272-282. doi: 10.1016/j. plantsci.2015.04.007

Foyer, C. H., and Noctor, G. (2011). Ascorbate and glutathione: the heart of the redox hub. Plant Physiol. 155, 2-18. doi: 10.1104/pp.110.167569

Gunnaiah, R., Kushalappa, A. C., Duggavathi, R., Fox, S., and Somers, D. J. (2012). Integrated metabolo-proteomic approach to decipher the mechanisms by which wheat QTL (Fhb1) contributes to resistance against Fusarium graminearum. PLOS ONE 7:e40695. doi: 10.1371/journal.pone.0040695

Herrera-Vásquez, A., Salinas, P., and Holuigue, L. (2015). Salicylic acid and reactive oxygen species interplay in the transcriptional control of defense genes expression. Front. Plant Sci. 6:171. doi: 10.3389/fpls.2015.00171

Ho, Y. P., Tan, C. M., Li, M. Y., Lin, H., Deng, W. L., and Yang, J. Y. (2013). The AvrB_AvrC domain of AvrXccC of Xanthomonas campestris pv. campestris is required to elicit plant defense responses and manipulate ABA homeostasis. Mol. Plant Microbe Interact. 26, 419-430. doi: 10.1094/MPMI-06-120164-R

Husson, F., Le, S., and Josse, J. (2008). FactoMineR: an R package for multivariate analysis. J. Stat. Softw. 25, 1-18.

Iriti, M., Rossoni, M., Borgo, M., Ferrara, L., and Faoro, F. (2005). Induction of resistance to gray mold with benzothiadiazole modifies amino acid profile and increases proanthocyanidins in grape: primary versus secondary metabolism. J. Agric. Food Chem. 53, 9133-9139. doi: 10.1021/jf050853g
Kim, T. H., Lee, B. R., Jung, W. J., Kim, K. Y., Avice, J. C., and Ourry, A. (2004) De novo protein synthesis in relation to ammonia and proline accumulation in water stressed white clover. Funct. Plant Biol. 31, 847-855. doi: 10.1071/ FP04059

Kuźniak, E., and Sklodowska, A. (2005). Compartment-specific role of the ascorbate-glutathione cycle in the response of tomato leaf cells to Botrytis cinerea infection. J. Exp. Bot. 56, 921-933. doi: 10.1093/jxb/eri086

Lee, B. R., Jin, Y. L., Park, S. H., Zaman, R., Zhang, Q., Avice, J. C., et al. (2015). Genotypic variation in $\mathrm{N}$ uptake and assimilation estimated by $15 \mathrm{~N}$ tracing water deficit-stressed Brassica napus. Envrion. Exp. Bot. 109, 73-79. doi: 10.1016/j.envexpbot.2014.08.004

Lee, B. R., Kim, K. Y., Jung, W. J., Avice, J. C., Ourry, A., and Kim, T. H. (2007). Peroxidases and lignification in relation to the intensity of water-deficit stress in white clover (Trifolium repens L.). J. Exp. Bot. 58, 1271-1279. doi: 10.1093/jxb/ erl280

Lee, B. R., Li, L. S., Jung, W. J., Jin, Y. L., Avice, J. C., Ourry, A., et al. (2009). Water deficit-induced oxidative stress and the activation of antioxidant enzymes in white clover leaves. Biol. Plant 53, 505-510. doi: 10.1007/s10535-009-0091-2

Lee, B. R., Muneer, S., Park, S. H., Zhang, Q., and Kim, T. H. (2013). Ammonium-induced proline and sucrose accumulation, and their significance in antioxidative activity and osmotic adjustment. Acta Physiol. Plant. 35, 2655-2664. doi: 10.1007/s11738-013-1297-7

Lee, B. R., Zaman, R., Avice, J. C., Ourry, A., and Kim, T. H. (2016). Sulfur use efficiency is a significant determinant of drought stress tolerance in relation to photosynthetic activity in Brassica napus cultivars. Front. Plant Sci. 7:459. doi: $10.3389 /$ fpls. 2016.00459

Livak, J. K., and Schmittgen, T. D. (2001). Analysis of relative gene expression data using real-time quantitative PCR and the $2^{-\Delta \Delta C_{t}}$ method. Methods 25, 402-408. doi: 10.1006/meth.2001.1262

Martínez-Medina, A., Fernandez, I., Lok, G. B., Pozo, M. J., Pieterse, C. M. J., and Wees, S. C. M. V. (2017). Shifting from priming of salicylic acid- to jasmonic acid regulated defences by Trichoderma protects tomato against the root knot nematode Meloidogyne incognita. New Phytol. 213, 1363-1377. doi: 10.1111/ nph. 14251

Mohr, P. G., and Cahill, D. M. (2003). Abscisic acid influences the susceptibility of Arabidopsis thaliana to Pseudomonas syringae pv. tomato and Peronospora parasitica. Funct. Plant Biol. 30, 461-469. doi: 10.1071/FP02231

Muneer, S., Lee, B. R., Bae, D. W., and Kim, T. H. (2013). Changes in expression of proteins involved in alleviation of Fe-deficiency by sulfur nutrition in Brassica napus L. Acta Physiol. Plant. 35, 3037-3045. doi: 10.1007/s11738-013-1336-4

O'Donnell, P., Jones, J., Antoine, F., Ciardi, J., and Klee, H. (2001). Ethylenedependent salicylic acid regulates an expanded cell death response to a plant pathogen. Plant J. 25, 315-323. doi: 10.1046/j.1365-313x.2001.00968.x

O’Donnell, P. J., Schmelz, E. A., Moussatche, P., Lund, S. T., Jones, J. B., and Klee, H. J. (2003). Susceptible to intolerance - a range of hormonal actions in a susceptible Arabidopsis pathogen response. Plant J. 33, 245-257. doi: 10.1046/j. 1365-313X.2003.01619.x

Pan, X. Q., Welti, R., and Wang, W. M. (2010). Quantitative analysis of major plant hormones in crude plant extracts by high-performance liquid chromatographymass spectrometry. Nat. Protoc. 5, 986-992. doi: 10.1038/nprot.2010.37

Pieterse, C. M. J., Does, D. V., Zamioudis, C., Leon-Reyes, A., and van Wees, S. C. M. (2012). Hormonal modulation of plant immunity. Annu. Rev. Cell Dev. Biol. 28, 489-521. doi: 10.1146/annurev-cellbio-092910-154055

Pieterse, C. M. J., Leon Reyes, H. A., van der Ent, S., and van Wees, S. C. M. (2009). Networking by small-molecule hormones in plant immunity. Nat. Chem. Biol. 5, 308-316. doi: 10.1038/nchembio. 164

Prior, R. L., Fan, E., Ji, H., Amy, H., Nio, C., Payne, M. J., et al. (2010). Multilaboratory validation of a standard method for quantifying proanthocyanidins in cranberry powders. J. Sci. Food Agric. 90, 1473-1478. doi: 10.1002/jsfa.3966

Queval, G., and Noctor, G. (2007). A plate reader method for the measurement of NAD, NADP, glutathione, and ascorbate in tissue extracts: application to redox profiling during Arabidopsis rosette development. Anal. Biochem. 363, 58-69. doi: 10.1016/j.ab.2007.01.005

Rahman, I., Kode, A., and Biswas, S. K. (2006). Assay for quantitative determination of glutathione and glutathione disulfide levels using enzymatic recycling method. Nat. Protoc. 1, 3159-3165. doi: 10.1038/nprot.2006.378

Sánchez-Vallet, A., López, G., Ramos, B., Delgado-Cerezo, M., Riviere, M. P., Llorente, F., et al. (2012). Disruption of abscisic acid signaling constitutively 
activates Arabidopsis resistance to the necrotrophic fungus Plectosphaerella cucumerina. Plant Physiol. 160, 2109-2124. doi: 10.1104/pp.112.200154

Shinde, S., Villamor, J. G., Lin, W., Sharma, S., and Verslues, P. E. (2016). Proline coordination with fatty acid synthesis and redox metabolism of chloroplast and mitochondria. Plant Physiol. 172, 1074-1088. doi: 10.1104/pp.16.01097

Silva, H. A. S., Romeiro, R. S., Macagnan, D., Halfeld-Vieira, B. A., Pereira, M. C. B., and Mounteer, A. (2004). Rhizobacterial induction of systemic resistance in tomato plants: nonspecific protection a decrease in enzyme activities. Biol. Control. 29, 288-295. doi: 10.1016/S1049-9644(03)00163-4

Spoel, S. H., Johnson, J. S., and Dong, X. (2007). Regulation of tradeoffs between plant defenses against pathogens with different lifestyles. Proc. Natl. Acad. Sci. U.S.A. 104, 18842-18847. doi: 10.1073/pnas.0708139104

Štefan, M. B., Rodríguez, J. V., Blažeković, B., Kindl, M., and Vladimir-Knežević, S. (2014). Total hydroxycinnamic acids assay: prevalidation and application on Lamiaceae Species. Food Anal. Methods 7, 326-336. doi: 10.1007/s12161-0139630-8

Velasco, P., Lema, M., Francisco, M., Soengas, P., and Cartea, M. E. (2013). In Vivo and in vitro effects of secondary metabolites against Xanthomonas campestris pv. campestris. Molecules 18, 11131-11143. doi: 10.3390/molecules180911131

Venisse, J. S., Gullner, G., and Brisset, M. N. (2001). Evidence for the involvement of an oxidative stress in the initiation of infection of pear by Erwinia amylovora. Plant Physiol. 125, 2164-2172. doi: 10.1104/pp.125.4.2164

Xia, X. J., Zhou, Y. H., Shi, K., Zhou, J., Foyer, C. H., and Yu, J. Q. (2015). Interplay between reactive oxygen species and hormones in the control of plant development and stress tolerance. J. Exp. Bot. 66, 2839-2856. doi: 10.1093/jxb/ erv089

Xu, R. Q., Blanvillain, S., Feng, J. X., Jiang, B. L., Li, X. Z., Wei, H. Y., et al. (2008). $\operatorname{AvrAC}(\mathrm{Xcc} 8004)$, a type III effector with a leucine-rich repeat domain from Xanthomonas campestris pathovar campestris confers avirulence in vascular tissues of Arabidopsis thaliana ecotype Col-0. J. Bacteriol. 190, 343-355. doi: 10.1128/JB.00978-07

Zhishen, J., Mengcheng, T., and Jianming, W. (1999). The determination of flavonoid contents in mulberry and their scavenging effects on superoxide radicals. Food Chem. 64, 555-559. doi: 10.1016/S0308-8146(98)00102-2

Zhou, J., Wang, J., Li, X., Xia, X. J., Zhou, Y. H., Shi, K., et al. (2014). H2O2 mediates the crosstalk of brassinosteroid and abscisic acid in tomato responses to heat and oxidative stresses. J. Exp. Bot. 65, 4371-4383. doi: 10.1093/jxb/eru217

Conflict of Interest Statement: The authors declare that the research was conducted in the absence of any commercial or financial relationships that could be construed as a potential conflict of interest.

Copyright ( $\odot 2017$ Islam, Lee, Park, La, Bae and Kim. This is an open-access article distributed under the terms of the Creative Commons Attribution License (CC BY). The use, distribution or reproduction in other forums is permitted, provided the original author(s) or licensor are credited and that the original publication in this journal is cited, in accordance with accepted academic practice. No use, distribution or reproduction is permitted which does not comply with these terms. 